doi: $10.15407 /$ ukrbotj72.06.585

\author{
M.V. PIROGOV \\ Ivan Franko National University of Lviv \\ 4, Hrushevskyi Str., Lviv, 79005, Ukraine \\ nikola.pirogov@gmail.com
}

\title{
CLYPEOCOCCUM CETRARIAE (DACAMPIACEAE, ASCOMYCOTA) IN THE UKRAINIAN CARPATHIANS
}

\begin{abstract}
Pirogov M.V. Clypeococcum cetrariae (Dacampiaceae, Ascomycota) in the Ukrainian Carpathians. - Ukr. Bot. J. 2015. - 72(6): 585-587.

Clypeococcum cetrariae Hafellner is a new species for biota of Ukraine. The specimens of Cetraria islandica (L.) Ach. infected by this fungus were collected in the Chornohora Mts. (Eastern Carpathians, Ukraine). Clypeococcum cetrariae is a little known species of lichenicolous fungi in the world, therefore in the paper a description of this species and figures are given. A key to Clypeococcum D. Hawksw. species is also provided.
\end{abstract}

K e y w o r d s: lichenicolous fungi, Cetraria islandica, Chornohora, Eastern Carpathians, Ukraine

The genus Clypeococcum D. Hawksw. was described in 1977 (Hawksworth, 1977). The species of the genus have numerous black spherical pseudothecia that are united in groups by a common black clypeus (C. galloides Etayo and C. grossum (Körber) D. Hawksw. form convex galls); pseudothecial wall composed of brown to dark brown pigmented cells, textura intricata-like but sometimes becoming pseudoparenchymatous at maturity; hymenium I- and KI- (in C. galloides I+ and KI+ violaceous); pseudoparaphyses remaining distinct, filiform, hyaline, septate, sparsely branched and anastomosing; periphyses not clearly defferentiated or having short periphysoids; asci subcylindrical, short-stalked, bitunicate, with a distinct internal apical beak, 2-, 4- or 8-spored; ascospores dark brown, uniseptate, ellipsoid, with delicately verruculose walls; conidiomata pycnidial, immersed; conidia hyaline, simple, bacilliform (Ertz, 2004). At present, 9 species of the genus Clypeococcum are known: C. bisporum Zhurb., C. cetrariae Hafellner, C. cladonema (Wedd.) D. Hawksw., C. epimelanostolum (D. Hawksw. \& Øvstedal) Grube \& Hafellner, C. galloides, C. grossum, C. hypocenomycis D. Hawksw., C. placopsiiphilum Øvstedal \& D. Hawksw. and C. psoromatis (A. Massal.) Etayo (Lawrey, Diederich, 2011). The Clypeococcum species grow on thallus of lichens from the genera: Buellia De Not., Cetraria Ach., Cetrelia W.L. Culb. et C.F. Culb., Flavocetraria Kärnefelt et A. Thell, Hypocenomyce M. Choisy, Lecidea Ach., Xanthoparmelia (Vain.) Hale, Placopsis (Nyl.) Linds., Squamarina Poelt, Umbilicaria Hoffm., etc. Clypeococcum species are distributed in North Africa, North and South Americas, Europe, Antarctica and New Zealand.

(C) M.V. PIROGOV, 2015
The genus Clypeococcum was first time reported for Ukraine in 2010 from the Ukrainian Roztochia (Pirogov, 2010). In this paper Clypeococcum hypocenomycis collected on thallus of Hypocenomyce scalaris (Ach. ex Lilj.) M. Choisy is reported.

In 2012, the second species of Clypeococcum, C. cladonema, was found in Kyiv Region (Prekrasna et al., 2012). This species was collected on thallus of Cetraria islandica by O. Nadeina. In 2013 we collected Cetraria islandica (L.) Ach. with lichenicolous fungi in the Chornohora Mts. (Eastern Carpathians, Ukraine). The detailed study of these herbarium specimens showed that this fungus is Clypeococcum cetrariae, a new species of lichenicolous fungi for Ukraine. This fungus is a little known species in the world. The description and figures of Clypeococcum cetrariae are given in this short report. At the end of the paper, a key for identification of all Clypeococcum species is given.

The herbarium specimens were collected and studied according to standard methods (Smith et al., 2009). The ascomata details of Clypeoccum cetrariae were examined on handmaid sections in water. The herbarium collections are deposited in the Herbarium of Ivan Franko National University of Lviv $(L W)$.

\section{Clypeococcum cetrariae Hafellner Mitt. naturw. Ver. Steierm. 125: 83 (1996)}

Mycelium: immersed in the thallus of lichen. Hyphae: brown, flexuous, frequently branching, thinwalled. Pseudothecia: immersed, globose, ostiolate, young 35-50 × 41-50 $\mu \mathrm{m}$, mature $65-75 \times 85-90 \mu \mathrm{m}$, arising in groups united by a common clypeus that remains largely immersed, the clypeus comprising hyphae of the host and invading fungus, finally dark brown to 
black. Pseudothecial wall: $6-15 \mu \mathrm{m}$ thick, thickest near the ostiole where it is scarcely delimited from the tissues of the clypeus, formed of intertwined thick-walled, dark brown hyphae. Hymenium: hyaline, 50-60 $\mu \mathrm{m}$ tall. Subhymenium: hyaline, $10-15 \mu \mathrm{m}$ thick. Pseudoparaphyses: distinct, persistent, filiform, branched and anastomosing, septate, 1-2 $\mu \mathrm{m}$ thick. Periphyses: not clearly differentiated (?). Asci: cylindrical, with a distinct internal apical beak when young, 43-46 × 10-13 $\mu \mathrm{m}, 4$-spored. Ascospores: olivaceous brown, 1-septate, ellipsoid to soleiform, rounded at the apices, slightly constricted at the septum, the lower cell often somewhat narrower, often guttulate, weakly verruculose, 14 $16(-17.1) \times(4.9-) 5-6(-6.2) \mu \mathrm{m}$. Pycnidia: not seen in the Ukrainian sample (see color figure on supplementary sheet).

Host: thalli of Cetraria islandica.

World distribution: Austria (Hafellner, 1996); Estonia, Latvia, Poland (Suija, 2005); Siberian Arctic, Russia (A checklist ..., 2009), and Ukraine (this paper).

Specimens studied: Ukraine, Zakarpattia Region, Rakhiv District, neighborhood of Kvasy village, Sheshul Mt., 48 09'01.6"N 2421'41.1"E, 1683 m alt., 28.06.2013, M. Pirogov (2668, 2669 LW).

\section{Key to Clypeococcum species}

1. Asci at the beginning with 8 spore initials, but constantly 2-spored when mature, ascospores (17-)20$27(-35) \times(4-) 5-5.5(-6) \mu \mathrm{m}$, on thallus of Cetraria laevigata and Flavocetraria cucullata ....... Clypeococcum bisporum Zhurb.

- Asci with (2)4 ascospores 2

- Asci with 8 ascospores 3

2. Asci with 4 ascospores, ascospores $8-10 \times 5-7 \mu \mathrm{m}$, on the thallus of Buellia melanostola ......... Clypeococcum epimelanostolum (D. Hawksw. \& Øvstedal) Grube \& Hafellner

- Asci with (2) 4 ascospores, ascospores 11.5-14(-16) $\times$ 5.5-7(-8) $\mu \mathrm{m}$, on thallus of Lecidea sp. ... Clypeococcum galloides Etayo

- Asci with 4 ascospores, ascospores 14-16($17.1) \times(4.9-) 5-6(-6.2) \mu \mathrm{m}$, on thallus of Cetraria islandica Clypeococcum cetrariae Hafellner

3. Ascospores mainly exceeding $7 \mu \mathrm{m}$ wide 4

- Ascospores less than $7 \mu \mathrm{m}$ wide 5

4. Ascospores (15-)19-22(-26) × (6-)7-9(-10) $\mu \mathrm{m}$, ascomata $60-120(-150) \mu \mathrm{m}$ diam., arising in necrotic patches on several Squamarina species .... Clypeococcum psoromatis (A. Massal.) Etayo (= C. epicrassum (H. Olivier) Hafellner \& Nav.-Ros.)

- Ascospores 14-17(-21) $\times 7-10 \mu \mathrm{m}$, ascomata convex gall-like structures $250-350(-700) \mu \mathrm{m}$ diam., on Umbilicaria vellea and Umbilicaria cinereascens Clypeococcum grossum (Körber) D.

Hawksw.

- Ascospores (15-)15.5-21(-25) × (7-) 7.5-8.5(9) $\mu \mathrm{m}$, on thallus of Placopsis species ............ Clypeococcum placopsiiphilum Ovstedal \& D. Hawksw.

5. Ascospores (13.5-) 14-16(-18) × (5.5-)6-7(7.5) $\mu \mathrm{m}$, ascomata mainly $60-150 \mu \mathrm{m}$, aggregated in groups of 10-20, parasitic on Cetrelia olivetorum on which it forms neat round holes in the thallus, and also on Xanthoparmelia pulla cladonema (Weddell) D. Hawksw.

- Ascospores (9-)10-12(-13) × (4-)5-6(-6.5) $\mu \mathrm{m}$, ascomata $50-100 \mu \mathrm{m}$, aggregated in groups of less than 10, parasitic on Hypocenomyce scalaris, infected squamules becoming brown, bleached and finally dead Clypeococcum hypocenomycis $\mathrm{D}$. Hawksw.

Acknowledgment: Author is very grateful to Prof. Sergiy Kondratyuk (Ukraine) and Dr. Paul Diederich (Luxembourg) for the help in collecting information about Clypeococcum species.

\section{REFERENCES}

A checklist of the lichen flora of Russia, St. Petersburg, 2009, 171 pр. [Список лихенофлоры России. - Санкт-Петербург, 2009. - 171 с.].

Ertz D. Clypeococcum. In: Lichen Flora of the Greater Sonoran Desert Region. Eds T.H. Nash III, B.D. Ryan, P. Diederich, C. Gries, F. Bungartz, Tempe: Arizona State University, 2004, vol. 2, pp. 641-642.

Etayo J. Hongos liquenícolas de Perú homenaje a Rolf Santesson, Bull. Soc. Linn. Provence, 2010, 61, pp. 1-46.

Etayo J., Triebel D. New and interesting lichenicolous fungi at the Botanische Staatssammlung München, The Lichenologist, 2010, 42(3), pp. 231-240. doi:10.1017/ S0024282909990417.

Hafellner J. Beiträge zu einem Prodromus der lichenicolen Pilze Österreichs und angrenzender Gebiete. II. Über einige in der Steiermark erstmals gefundene Arten, Mitt. naturwiss. Ver. Steiermark, 1996, 125, pp. 73-88.

Hawksworth D.L. Three new genera of lichenicolous fungi, Bot. J. Lin. Soc., 1977, 75, pp. 195-209.

Hawksworth D.L. Notes on British lichenicolous fungi: III, Notes RBG Edinb., 1980, 38(1), pp. 165-183.

Ihlen P.G., Wedin M. An annotated key to the lichenicolous Ascomycota (including mitosporic morphs) of Sweden, Nova Hedwigia, 2008, 86(3-4), pp. 275-365. doi:10.1127/0029-5035/2008/0086-0275. 
Lawrey J. D., Diederich P. Lichenicolous fungi - worldwide checklist, including isolated cultures and sequences available, available at: http://www.lichenicolous.net, 2011 (accessed 10 November 2015).

Navarro-Rosinés P., Roux C., Llimona X. Nelikeniĝintaj fungoj ce Squamarina: Clypeococcum epicrassum comb. nov. kaj Lichenochora clauzadei sp. nov. (Ascomycetes), Bull. Soc. Linn. Provence, 1994, 45, pp. 421-429.

Pirogov N.V. Chornomors'k. bot. z., 2010, 6(2), pp. 276279. [Пірогов М.В. Clypeococcum hypocenomycis D. Hawksw. - новий для України вид ліхенофільного гриба // Чорноморськ. ботан. журн. - 2010. - 6(2). - С. 276-279].

Prekrasna E., Vasyliuk O., Domashevskii S., Parnikosa I., Fatikova M., Nadeina O., Norenko K. Proektovanyi nacionalnyi pryrodnyi park «Divichki» u Kyivs'kii oblasti. In: Zberezhemo ukrainski stepy, Kyiv: NECU, 2012, 44 pp. [Прекрасна Є., Василюк О., Домашевський С., Парнікоза I., Фатікова М., Надєіна О., Норенко К. Проектований національний природний парк «Дівички» у Київській області. Серія: Збережемо українські степи. - К.: НЕЦУ, 2012. - 44 с.].

Suija A. Lichenicolous fungi and lichens in Estonia I. Ascomycota, Nova Hedwigia, 2005, 80, pp. 247-267. doi:10.1127/0029-5035/2005/0080-0247.

The lichens of Great Britain and Ireland. Eds C.W. Smith, A. Aptroot, B.J. Coppins, A. Fletcher, O.L. Gilbrt, P.W. James, P.W. Wolseley, London: The British Lichen Society, 2009, 1046 pp.

Zhurbenko M.P. Lichenicolous fungi and some lichens from the Holarctic, Opuscula Philolichenum, 2009, 6, pp. $87-120$.

Recommended for publication

Submitted 08.10.2015

by S.Y. Kondratyuk
Пірогов М.В. Clypeococcum cetrariae (Dacampiaceae, Ascomycota) в Українських Карпатах. - Укр. ботан. журн. - 2015. - 72(6): 585-587.

Львівський національний університет імені Івана Франка вул. Грушевського, 4, м. Львів, 79005, Україна

Clypeococcum cetrariae Hafellner - новий вид для біоти України. Гербарні зразки лишайника Cetraria islandica (L.) Ach., інфіковані грибом, зібрані на території хребта Чорногора (Східні Карпати, Україна). Clyреососсит cetrariae є маловідомим видом ліхенофільних грибів у світовій біоті, тому в статті подано його опис, матеріал ілюстрований оригінальними фотографіями. Також наведено ключ для визначення видів роду Clyреососсит D. Hawksw.

К л ю ч о в і с л о в а: ліхенофільні гриби, Cetraria islandica, хребет Чорногора, Східні Карпати, Україна

Пирогов Н.В. Clypeococcum cetrariae (Dacampiaceae, Ascomycota) в Украинских Карпатах. - Укр. ботан. журн. - 2015. - 72(6): 585-587.

Львовский национальный университет имени Ивана Франко ул. Грушевского, 4, г. Львов, 79005, Украина

Clypeococcum cetrariae Hafellner - новый вид для биоты Украины. Гербарные образцы лишайника Cetraria islandica (L.) Ach., инфицированные грибом, собраны на территории хребта Черногора (Восточные Карпаты, Украина). Clypeococcum cetrariae является малоизвестным видом лихенофильных грибов в мировой биоте и поэтому в статье дано его описание, материал иллюстрирован оригинальными фотографиями. Также приведен ключ для определения видов рода Clypeоcoccum D. Hawksw.

К л ю ч е в ы е с л о в а: лихенофильные грибы, Cetraria islandica, хребет Черногора, Восточные Карпаты, Украина. 

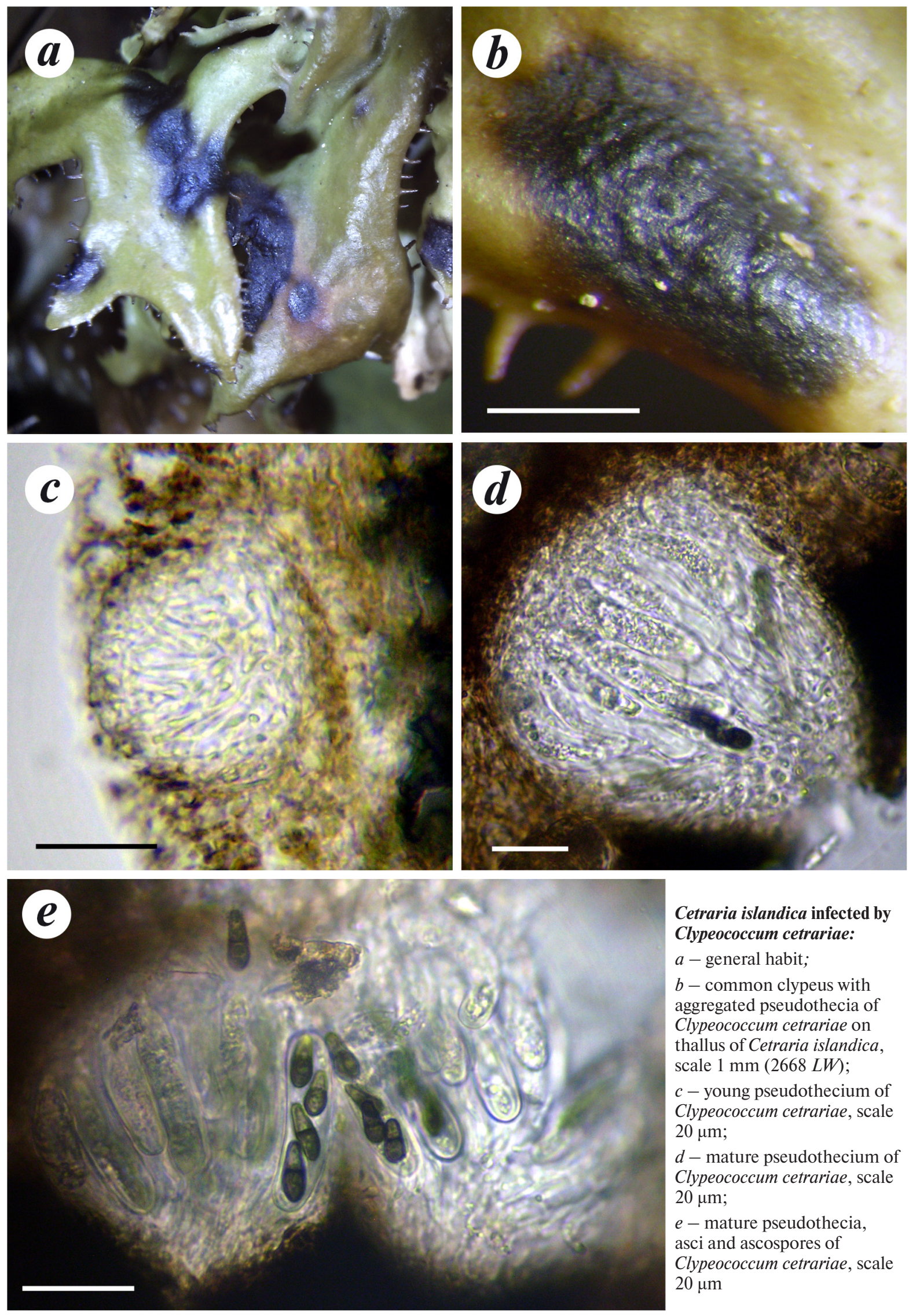

Cetraria islandica infected by Clypeococcum cetrariae:

$a$ - general habit;

$b$ - common clypeus with aggregated pseudothecia of Clypeococcum cetrariae on thallus of Cetraria islandica, scale $1 \mathrm{~mm}(2668 \mathrm{LW})$; $c$-young pseudothecium of Clypeococcum cetrariae, scale $20 \mu \mathrm{m}$;

$d$ - mature pseudothecium of Clypeococcum cetrariae, scale $20 \mu \mathrm{m}$;

$e-$ mature pseudothecia, asci and ascospores of Clypeococcum cetrariae, scale $20 \mu \mathrm{m}$ 